\title{
A Report on the 11th FCCA Seminar "The Taste of Glycoprotein Sugar Chains"
}

\author{
第11回FCCA セミナー"甘くはない糖タンパク質糖鎖の機能"報告
}

\author{
Kiyoshi Furukawa \\ Department of Biochemistry, Institute of Medical Science, University of Tokyo, \\ Minato-ku, Tokyo 108, Japan, FAX: 81-3-3443-8508
}

Key Words: glycoprotein sugar chain, cell adhesion, $\beta 1$, 4-galactosyltransferase, mucin, tumor cell metastasis

Theme: The Taste of Glycoprotein Sugar Chains.

Organizer: Kiyoshi Furukawa(Department of Biochemistry, Institute of Medical Science,University of Tokyo Phone: 81-3-3443-8111

Date: August 30, 1991(FRI) 1-5 pm

Place: The Kitasato Institute(5-9-1 Shirokane, Minato-ku, Tokyo 108, Phone: 81-3-3444-6161)

\section{Program:}

1. The Role of Glycosylation in Integrin Family Steven K. Akiyama, Laboratory of Developmental Biology, National Institute of Dental Research, NIH

2. Kinetic Study of $\beta 1,4-$ Galactosyltransferase Expressed by COS-1 Cells and by $E$. coli

Kazutoshi Nakazawa, Institute of Physical and Chemical Research

3. Ectopic Expression of Mucins in Colorectal Cancer Metastasis

Tatsuro Irimura, M D Anderson Cancer Center, University of Texas
テーマ: 甘くはない糖タンパク質糖鎖の機能

オーガナイザー: 古川 清(東京大学医科学研究所 細胞生物化学研究部)

日 時: 平成3年8月30日(金)午後1-5時

場所: 北里研究所3号館1階会議室

プログラム:

1.インテグリン分子の糖鎖の機能

Akiyama, Steven K. (Laboratory of Developmental

Biology, National Institute of Dental Research, NIH)

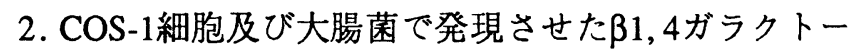

ス転移酵素の酵素学的解析

中沢一俊(理化学研究所)

3. 転移性大腸癌に見られるムチンの異所性発現

入村達郎(M D Anderson Cancer Center, University of Texas)

\section{A. Introduction}

Many proteins synthesized in animal cells are glycosylated. The glycosylation mechanism includes many complex steps to build up mature forms of the sugar chains, but this post translational modification is found throughout the animal kingdom. Since it has survived through evolution, it is considered that the protein modification must be important for maintaining the life of animals. In fact, the sugar chains of proteins play important roles in a variety of biological systems such as embryonic development, lymphocyte recirculation, immuno surveilance and tumor cell metastasis. More recently, interest in biological roles of glycoprotein sugar chains has been intensified with the identification of the ligands for several inflammatory cell adhesion molecules, the LEC-CAMs.

The glycoprotein sugar chains as mentioned above have a positive aspect in the biological systems, while the carbohy-
A.はじめに

動物細胞で合成される蛋白質の多くは、糖鎖修飾を受け る。この糖鎖修飾機構は精巧かつ複雑であるが、原生動物から 脊椎動物に至るまで普遍的に存在している。従って、この蛋白 質修飾機構は自然淘汰に打ち勝って生き延びてきた機構であ ク、生命の維持にいまもって重要であると考えられる。実際糖 蛋白質の糖鎖は、胚発生、リンパ球の再循環、免疫監視機構、 癌細胞の転移などで見られる細胞間接着に重要な役割を果たし ている。ごく最近になって、炎症時に見られる細胞間接着に関 与する分子のリガンドが糖鎖であることが判明するに及んで、 糖蛋白質糖鎖の生物学的機能も一段と脚光を浴びてきた。

このように、桾蛋白質糖鎖は生体内で重要な役割を果たし ている一方、癌細胞表面に発現する糖鎖のように転移に関与す るものもあり、桾鎖は必ずしも生体にとり甘いものではない。 このような背景から、今回のFCCAセミナーでは3人の演者から それぞれの研究で扱っている桾蛋白質糖鎖の味を紹介して頂く 
drate antigens expressed on tumor cells have a negative aspect in terms of involvement in metastasis of tumor cells. Therefore, the taste of glycoprotein sugar chains is not always sweet. In the present FCCA seminar, we asked three speakers, Drs. Steven K. Akiyama, Kazutoshi Nakazawa, and Tatsuro Irimura for providing us the taste of the sugar chains of their materials currently studying.

\section{B. The Role of Glycosylation in the Integrin Family.}

Cell surface carbohydrates have long been implicated to be involved in cell interactions. In fact, structural changes in cell surface carbohydrates during the course of embryonic development and malignant transformation of cells have been observed in association with the changes in cell to cell and cell to substratum interactions. Recent reports evidenced that the sugar chains of proteins modify the protein functions, in addition to the direct involvement of them as ligands for the cell adhesion molecules. One of the cases is observed in glycosylation of the cell surface receptor for fibronectin. Dr. Akiyama together with Dr. K. Yamada in NIH has studied of fibronectin for a long time and tried to elucidate molecular mechanisms of cell adhesion by analyzing the interaction of fibronectin with its cell surface receptors, the integrins.

Firstly, Akiyama showed the molecular anatomy of fibronectin which contains multiple cell binding sites: the (Gly)Arg-Gly-Asp-(Ser)(RGD) sequence located in the central cell binding domain, the alternatively spliced IIICS region, and the region with molecular size of $16 \mathrm{kDa}$ located to the amino-terminal side of the RGD site within the central cell binding domain which functions synergistically with the RGD sequence in cell adhesion and migration as well as the assembly of extracellular fibronectin matrices. None of the three major cell adhesive regions are thought to be glycosylated.

Secondary, he described the cell surface receptors for fibronectin. The best characterized receptors belong to an integrin family. The integrins are transmembrane glycoproteins that integrate the external messages into cells. They are heterodimers composed of an $\alpha$-subunit of $140-180 \mathrm{kDa}$ and a $\beta$ subunit of $100-130 \mathrm{kDa}$. The $\alpha_{5} \beta_{1}$ integrin binds to the RGD and synergistic regions, and the $\alpha_{4} \beta_{1}$ integrin binds to the IIICS region. At least three other integrins have been found to bind to fibronectin. Among them, the $\alpha_{5} \beta_{1}$ integrin plays important roles in cell adhesion, migration, extracellular fibronectin matrix assembly, and the in vivo metastasis of certain types of carcinoma cells. The $\beta_{1}$ subunit is initially synthesized as a longlived precursor which is biologically inactive. Maturation of the $\beta_{1}$ integrin in normal cells involves the intracelluar processing of asparagine-linked sugar chains which appear to result in the formation of an usually large glycan structure and an increase in the size of the $\beta_{1}$ subunit by approximately $20 \mathrm{kDa}$.

When maturation of asparagine-linked sugar chains was
ことで、糖鎖の機能を考えてみた。

\section{B. インテグリン分子の裙鎖の機能}

多くの研究から細胞表面の糖鎖は、細胞間接着に関与して いることが示葰されてきた。実際、初期胚の発生や細胞の癌性 変化を通して、細胞表面糖鎖の構造变化と細胞間接着の変化が 対応して把えられている。一方最近の報告から、糖鎖が直接細 胞間接着に関与する以外に、糖蛋白質の糖鎖が蛋白質の機能を 調節しているケースも幾つか知られている。この一つの例が、 細胞表面に存在するフィブロネクチン受容体の糖鎖修飾におい て見られている。NIHのK.Yamada博士と共にAkiyama博士は長 い間フィブロネクチンに関する研究を行っており、フィブロネ クチンとその受容体であるインテグリン分子の結合を解析する ことで、細胞間接着の分子機構を明らかにしようと試みられて いる。

最初、演者はフィブロネクチン分子の性状を紹介し、特に 細胞結合部位の中央に位置するアルギニン-グリシン-アスパラ ギン酸のいわゆるRGD配列、IIICS部位、RGD配列のアミノ末 端に位置する分子量 $16 \mathrm{kDa}$ のつの領域が、それぞれ共同して 細胞間接着や細胞の愁㲜さらにフィブロネクチンを含む細胞外 マトリックスへの接着に関与していることを示した。興味深い ことに、これらの細胞結合部位は、いずれも糖鎖修飾を受けて いない。

次に演者は、細胞表面のフィブロネクチン受容体について 話された。フィブロネクチン受容体として、インテグリン分子 が知られている。インテグリン分子は細胞膜を貫通する糖蛋白 質であり、外界の情報を細胞内へ伝達する。一般に、この分子 は分子量140-180 kDaの $\alpha$-サブユニットと、分子量100-130 kDa の阬ブユニットから構成されている。 $\alpha_{5} \beta_{1}$ インテグリンは、 フィブロネクチンのRGDペプチドとその近傍の分子量 $16 \mathrm{kDa}$ の 部位と䊅合し、 $\alpha_{4} \beta_{1}$ インテグリンは IIICS部位と䊅合する。この ほかにも、3つのインテグリン分子が、フィブロネクチンに䊅合 することが知られている。これらのインテグリン分子の中で も、特に $\alpha_{s} \beta_{1}$ インテグリン分子が生物学的に重要である。

通常倩サブユニットは、長い半減期をもつ生物学的に不活 性な前駆体として合成され、そのアスパラギン残基に糖鎖修飾 を受けて約 $20 \mathrm{kDa}$ の分子量を獲得して、 $\beta_{1}$ サブユニットとして の機能蛋白質になる。このアスパラギン結合型糖鎖のプロセシ ングを、細胞の培養液に1-デオキシマンノジリマイシン(MNJ) を加えて阻害すると、この細胞から精製した $\alpha_{5} \beta_{1}$ インテグリン 分子はフィブロネクチン-カラムに結合できなくなる。したがっ てこの結果から、 $\alpha_{5} \beta_{1}$ インテグリン分子のフィブロネクチンへ の結合には、糖鎖のブロセシンが重要であることが判明した。

一方、この糖鎖のプロセシングの有無は、 $\alpha_{s} \beta_{1}$ インテグリンの 会合や細胞膜への局在化には全く関与していなかった。同様の 知見が創傷治瘦過程で見られ、ここではケラチノサイトの话性 化に、やはりそのアスパラギン結合型糖鎖のプロセシングが必 要であることが判明している。

要約すると、蛋白質に結合している糖鎖は、この場合イン 
inhibited by treating cells with 1-deoxymannojirimycin(MNJ) which blocks the processing of high mannose-type sugar chains, the fibronectin binding activity of the $\alpha_{5} \beta_{1}$ integrin was also inhibited, suggesting that complete maturation of asparagine-linked sugar chains is necessary for the acquisition of full fibronectin binding activity by this receptor. In contrast, neither plasma membrane insertion nor association of the two subunits of the $\alpha_{5} \beta_{1}$ integrin was inhibited in MNJ treated cells. Further, the similar result has been observed in the activation of keratinocytes which requires maturation of asparagine-linked sugar chains in the process of wound healing.

His overall talk indicated that protein associated sugar chains are, indeed, involved in the control of cell adhesion by modifying the function of the integrin in this case. Therefore, structural changes in cell surface carbohydrates induced by malignant transformation of cells must be linked directly to the altered properties of the cells.

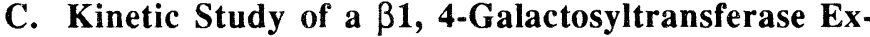 pressed in COS-1 Cells and $E$. coli.}

Due to an absence of the template activity in genetic codes toward carbohydrates, sugar chains with respective structures can only be reproduced by sequential action of glycosyltransferases, each of which has a strict substrate specificity. Although a number of glycosyltransferases have been characterized, little is known about their fine substrate specificities. Dr. Nakazawa and his colleagues have succeeded in expression of a $\beta 1,4$-galactosyltransferase in COS-1 cells by transfection of the mouse cDNA and in $E$. coli by transfection of the human cDNA, and characterized their enzymatic properties including the substrate specificity.

In the former part of his talk, kinetic study showed that the expressed enzymes with full glycosylation by COS-1 cells and presumably without glycosylation by $E$. coli have the same apparent $\mathrm{Km}$ values toward sugar donor, UDP-Gal, and sugar acceptors, $\mathrm{N}$-acetylglucosamine and $\mathrm{N}$-acetylglucosamine terminating glycoproteins. Therefore, in this case, glycosylation may not be important for the activity of the enzyme, and that the recombinant enzyme produced by $E$. coli can be useful to use in the in vitro synthesis of the Gal $\beta 1-4 \mathrm{GlcNAc}$ group containing oligosaccharides.

With use of this recombinant enzyme, the latter part of his talk included the tedious work that a series of oligosaccharides, glycoproteins and glycolipids are tested for its acceptor activity by determining the $\mathrm{Km}$ values in order to determine the fine substrate specificity of the enzyme. The results showed that $\mathrm{N}$-acetylglucosamine and asialo, agalacto-transferrin are the best acceptors for the enzyme, while ovine asialo-submaxillary mucin and glucosylceramide are not. Quite interestingly, relatively lower apparent $\mathrm{Km}$ values of the enzyme were obtained toward desulfated agalacto-keratan sulfate[GlcNAc $\beta 1$ -
テグリン分子の機能を調節することで、実際細胞間接着に関与 していることが明らかとなった。したがって、細胞の癌化など で生じる細胞表面糖鎖の変化は、細胞の性質変換と直接結びつ いていると考えられる。今後、インテグリン分子に結合してい るアスパラギン結合型糖鎖の構造解析、及びその蛋白質の機能 を調節する機構を解明する必要がある。

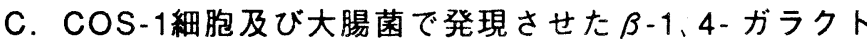
一ス転移酵秦の酳素学的解析

遺伝子上に糖鎖構造をコードする鋳型が存在しないので、 ある特定の構造を持つ糖鎖は、それぞれ厳密な基質特異性を 持った糖転移酵素の作用で合成される。これまで、多くの糖転 移酵素について研究がなされてきたが、その詳細な基質特異性 についてはほとんど解析されていない。演者らは、マウス $\beta 1$ 、 4-ガラクトース転移酵素のcDNAをCOS-1細胞に導入し一過性に この酵素を発現させたり、またヒト $\beta 1$ ，4-ガラクトース転移酵 素のcDNAを大腸菌に導入して酵素を発現させ、この酵素の性 質を調べてきた。

演者は前半の話で、COS-1細胞で発現させ糖鎖修飾を受け たこの糖転移酔素と、大腸菌で発現させ糖鎖修飾を欠く糖転移 䤃素を用いて、その糖供与体であるUDP-Gal 及び糖受容体であ るN-アセチルグルコサミンやN-アセチルグルコサミンを糖鎖非 還元末端にもつ糖蛋白質への $\mathrm{Km}$ 值を調べた結果、いずれも同じ 值であったことを示した。したがって、糖鎖修飾の有無と酵素 活性の間に相関はなく、大腸菌で発現させた組換え体産物はGal $\beta 1-4 \mathrm{GlcNAc}$ の二糖をもつオリゴ糖のin vitroの生合成に酵素と して用いることができる。

後半の話しは大腸菌の組換え体酵素を用いて、種々のオリ ゴ糖、糖蛋白質、糖脂質を基質にしたときの酵素の $\mathrm{Km}$ 值を調べ て、 $\beta 1 、 4-$ ガラクトース転移酵素の詳細な基質特異性を明らか にした。その結果、酵素はN-アセチルグルコサミンや脱シア ロ、脱ガラクトトランスフェリンを最もよい基質としたが、ヒツ ジ脱シアロ顎下腺ムチンやグルコシルセラミドは基質になりえ ないことが判明した。興味深いことに、ケラタン硫酸を脱硫酸 化し非還元末端のガラクトースを除きポリ-N-アセチルラクトサ ミン合成用の基質としたオリゴ糖、ラクト-N-トリオース、ラク トトリオシルセラミドに対する酵素の $\mathrm{Km}$ 值は、意外に低かった (論文準備中)。したがって、上記の基質にガラクトースを転移 する酵素は、糖蛋白質の $\beta 1$ ，4- ガラクトース転移酵素と同じで ある可能性が高い。

複合糖質には、100以上の異なる二糖構造が見出されてお ク、おのおのの二糖構造はそれぞれ異なる糖転移䣲素によって 作られると考えられている。したがって上記の結果を考慮する と、糖鎖のバックボーンが異なるオリゴ糖に見られる同じ二糖 構造が、同一の酵素により作られるのかどうか検討する必要が あり、これは同時に糖転移酵素がどこまで基質として認識する かという問題を解く鍵となる。

\section{D．転移性大腸癌に見られるムチンの異所性発現}


3(Gal $\left.\beta 1-4 \mathrm{GlcNAc})_{\mathbf{n}}\right]$ used as a substrate for poly $N$-acetyllactosamine synthesis, lacto- $N$-triose(GlcNAc $\beta 1-3 \mathrm{Gal} \beta 1-4 \mathrm{Glc}$ ), and lactotriaosylceramide(GlcNAc $\beta 1-3 \mathrm{Gal} \beta 1-4 \mathrm{Glc} \beta 1-\mathrm{Cer}$ ) (manuscript in preparation). Therefore, the enzyme that galactosylates the above substates may be identical to the glycoprotein $\beta 1$, 4-galactosyltransferase.

Since nearly 100 different disaccharide sequences are present in glycoconjugates and each sequence is thought to be made by a specific glycosyltransferase, it is important to determine whether the same disaccharide sequences found in different oligosaccharide back bones are made by one enzyme or not.

\section{Ectopic Expression of Mucins in Colorectal Cancer Me- tastasis.}

Mucins are glycoproteins rich in serine- and threoninelinked sugar chains, secreted by mucous tissues, and functioning in the protection of apical surfaces of glandular epithelial cells. It is known that tumors originated from epithelial cells often produce mucins, and such mucins ectopically expressed on the cell surfaces affect the biological properties of malignant cells. Dr. Irimura has studied the relationship between the mucin expression and tumor metastasis which is clinically the most important point for the treatment.

At the beginning of his talk, he showed us the morphological aspects of human colorectal carcinoma cells at various stages separated by the Dukes classification and their biochemical properties such as expression levels of cell adhesion molecules, mucins, and degradation enzymes, all of which are involved in the process of tumor metastasis. His talk indicated that complex changes including carbohydrate determinants on mucins occur during the progression and metastasis of human colorectal cancer cells.

Since normal gastric and intestinal mucins contain neutral and acidic forms, and since colorectal carcinoma cells produce mucin with $\mathrm{ABO} /$ Lewis blood group antigens whose peptide backbone is different from that of sialomucin, there must be several mucin core peptides. As expected, gene cloning of mucin core peptides revealed that currently there are three different genes designated as MUC1, MUC2, and MUC3 with characteristic tandem repeats in human genome. Northern blot analysis also showed that mammary gland mucin mRNA was detected in ectopic colorectal carcinoma cells.

Analyzing the types of mucins in human colorectal carcinoma samples with use of monoclonal antibodies, Irimura found that sialomucins and mucins with sialyl X[Neu5Aco2$3 \mathrm{Gal} \beta 1-4$ (Fuc $\alpha 1-3$ )GlcNAc] are expressed at higher levels in primary tumors with metastasis, while the levels of sulfomucins and mucins with blood group $\mathrm{H}$ antigen are decreased. Since the inflammatory cell adhesion molecule, ELAM-1, expressed on vascular endothelial cells recognizes and binds to the sialyl $\mathrm{X}$, tumors expressing mucins with sialyl $\mathrm{X}$ can adhere
ムチンは、セリンやスレオニンに䊅合した糖鎖に富む糖蛋 白質であり、粘液組織から分泌され、腺腔上皮細胞表面を保護 している。しかし、上皮系由来の癌細胞ではしばしばムチン合 成が見られ、このように異所性に産生されたムチンは、細胞の 性質を大きく変えていることが知られている。演者は、異所性 に発現されるムチンと外科治療の際に重要なポイントになる癌 転移との相関関保を研究している。

講演の最初に、演者はまずDukesの分類により区分された 種々のステージのヒト大腸癌の模式図を示し、これらのステー ジにある細胞の細胞接着分子、ムチン、分解醭素の発現量など いずれも癌の進行、転移に相関する生化学的因子との相関関保 を述べた。

一方、胃、腸のムチンには、中性ムチンや酸性ムチンが存 在したり、ヒト大腸癌で産生されるムチンでは $\mathrm{ABO} /$ Lewis 式血 液型抗原を発現するムチンのコア蛋白質が、シアロムチンのコ ア蛋白質と異なることから、ムチンにはコア蛋白質の構造が異 なるものが幾つかあると考えられていた。予想通り、ムチンの コア蛋白質の遺伝子のクローニングを通して、これまでヒトゲ ノム中にはMUC1、MUC2、MUC3と呼ばれる3つの遺伝子が見 つかり、それぞれ固有のタンデム・リピートをもつことが明ら かになっている。ノーザン・ブロット分析の結果、ヒト大腸癌 には本来乳腺で発現されるべきムチンのmRNAが発現している ことが見出されている。

多数のヒト大腸癌の検体にどのタイプのムチンが発現して いるかをモノクローナル抗体を用いて調べた結果、演者らはシ アロムチンやNeu5Ac $\alpha$ 2-3Gal $\beta$ 1-4(Fuc $\alpha$ 1-3)GlcNAcの構造の シアリルXをもつムチンの発現量が転移の認められる原発巣で 著しく増加するのに対して、硫酸化ムチンや血液型 $\mathrm{H}$ 抗原をも つムチンの産生量が低下することを見出した。炎症時に一過性 に血管内皮細胞に発現し、白血球との接着を司る細胞接着分子 ELAM-1のリガンドがこのシアリルXであることを考えると、シ アリルXをもつムチン産生癌細胞は血管内皮細胞に接着し、こ れが転移のプロセスの一歩となるのではないかと考えられる。 したがって、細胞表面に特定の糖鎖構造が発現することは、生 体にとり致命的である場合もある。

演者は、ヒト大腸癌で発現されるムチンのタイプは初期の 進行癌から後期の転移癌に移行するにしたがい変化し、この変 化は癌細胞のムチン遺伝子の発現の調節が効かなくなったため と考えられる旨を述べた。癌転移の分子機構の解明は、今もっ て大きな生物学的課題であるが、このムチンの異所性発現と癌 細胞の転移能獲得が同時に起こることから、癌細胞におけるム チン合成を解析することは、おそらくこの課題の本質を解く一 つの鍵となるであろう。

以上が、第11回FCCAセミナーの講演内容であるが、各講 演後活発な討論が行なわれた。夏休みの終わりであるにもかか わらず、60名をこえる多数の方々からセミナーに参加を頂き、 かつ折からの台風の熱気にも煽られて会場が盛り上がったこと は、このセミナーを企画した筆者にとり喜びであった。また、 今回はNIHからAkiyama博士を演者の一人に迎えたので、講演 
to the blood vessels, a step that is involved in metastasis of tumor cells. Thus, the expression of particular carbohydrate structures on the cell surfaces must be critical to individuals. His talk concluded that the expression of types of mucin in colorectal carcinoma cells is altered during tumor progression from early stage to advanced metastatic stage, and these changes apparently reflect a loss of tissue specific regulation of the mucin gene expression. Although the molecular basis of the tumor metastasis has to be elucidated, coincidence of an ectopic mucin expression with the acquisition of metastatic capability must be a key issue to solve this problem.
および質疑はすべて英語で行なってみた。国際学会で活躍する 若手が多い昨今、英語でのセミナーは我々にとっても勉強にな るものの、終始緊張を余儀なくされたのも事実であった。この セミナーに恒例のカン・ビールを片手に持って、リラックスし て話しを開こうとしたが、全体に未だその雾囲気から遠かった ように思われる。

アメリカの大学では、金曜日の午後によくビアー\&マンチ でファカルテイーと学生が集うハッピー・アワーがあり、話し に花か咲く。そんな雾囲気の集いに、このFCCAセミナーが発 展してくれたらと思う次第である。報告を終わるにあたり、こ の講演会を支えて頂いたFCCAセミナー運営委員の方々にお礼 を申しあげます。 